\title{
Elipsoideichnus meyeri Roselli 1987 revisited: A helicoidal fossil bee nest from the Paleogene of Uruguay
}

\author{
Mariano VERDE $E^{1^{*}} \&$ Jorge F. GENISE ${ }^{2}$
}

${ }^{1}$ SNI-ANII, PEDECIBA, Instituto de Ciencias Geológicas, Facultad de Ciencias, Universidad de la República, Iguá 4225, CP 11400, Montevideo, Uruguay; verde@fcien.edu.uy

${ }^{2}$ CONICET, Museo Argentino de Ciencias Naturales, División Icnología, Av. Ángel Gallardo 470, 1405, Buenos Aires, Argentina; jgenise@macn.gov.ar

* Corresponding author

Verde, M. \& Genise, J.F. 2014. Elipsoideichnus meyeri Roselli 1987 revisited: A helicoidal fossil bee nest from the Paleogene of Uruguay. [Revisión de Elipsoideichnus meyeri Roselli 1987: Un nido helicoidal fósil de abejas del Paleógeno de Uruguay]. Spanish Journal of Palaeontology, 29 (1), 25-32.

\begin{abstract}
The rare helicoidal trace fossil Elipsoideichnus meyeri Roselli 1987 was known only from its holotype. New materials were collected and revised, confirming the validity and interpretation of this ichnotaxon. Its previously inferred internal structure, composed of two pair of internal, opposite cells per whorl, was checked and completed with these new materials. Sections of specimens show that cells have a thick lining. The finding of a spiral cap in cells finally confirms that unknown bees are the trace makers of E. meyeri, possibly related with Oxaeinae or Halictinae.
\end{abstract}

Keywords: Elipsoideichnus meyeri, bee nest, Asencio Formation, Paleogene, Uruguay.

\section{RESUMEN}

La rara traza fósil helicoidal Elipsoideichnus meyeri Roselli 1987 sólo se conocía por su holotipo. Se ha colectado y revisado nuevo material que confirma la validez y la interpretación de este icnotaxon. Se comprueba la estructura interna deducida previamente, compuesta por dos pares de celdas internas opuestas por vuelta, y se completa con estos nuevos materiales. Las secciones de los especímenes muestran que las celdas poseen un grueso revestimiento. El hallazgo de una tapa espiral en las celdas finalmente confirma que los productores de E. meyeri fueron abejas de afinidad desconocida, posiblemente relacionadas con Oxaeinae o Halictinae.

Palabras clave: Elipsoideichnus meyeri, nido de abejas, Formación Asencio, Paleógeno, Uruguay. 


\section{INTRODUCTION}

Elipsoideichnus meyeri Roselli 1987 is perhaps one of the most complex and rare trace fossils found in paleosols. Along with Gyrolithes, Lapispira, and Eatonichnus among others (Bown et al., 1997; Gibert et al., 2012), Elipsoideichnus is one of the few helicoidal trace fossils described from invertebrates. Until now, this ichnotaxon had been only known from one locality of the early Eocene Asencio Formation in the southwestern region of Uruguay (Roselli, 1987).

The first reference to Elipsoideichnus in the literature appeared in 1976, when Roselli announced a forthcomming article about new insect fossil nests, including "a spiral palace" (palacio en espiral) of an ancient "Formidae" that inhabited the Uruguayan soils in the past. Eleven years later, Roselli (1987) formally described Elipsoideichnus meyeri (p. 36; Plate II, Fig. 4) based on one specimen. Despite the only specimen, Roselli described quite well the 3D morphology of this trace fossil. The bauplan of Elipsoideichnus meyeri as described by Roselli was basically a helicoidal tunnel, from which smooth lined, clavate cells arise, oppositely oriented. Roselli (1987) interpreted Elipsoideichnus meyeri as a hymenopteran nest based on cell morphology. In the same paper he also compared Elipsoideichnus meyeri with a recent ant ("Formidae") nest. However, it seems that Roselli was more probably referring to the common Uruguayan termite nests of Procornitermes, rather than a true ant nest.

In 1998, Genise \& Hazeldine published a morphological revision of Elipsoideichnus meyeri based on internal casts of the only one specimen known at that time. Applying software to reconstruct the 3D morphology of Elipsoideichnus, they improved Roselli's original description. The helicoidal morphology of Elipsoideichnus meyeri was decomposed into three main basic units: half whorls connected to cells by means of elbowed tunnels, whose repetition resulted in the whole trace fossil. They also inferred the behavioural sequence necessary for the construction of Elipsoideichnus meyeri, concluding that the helix was dextrogyrous, and that the original position of the trace fossil in the soil was with the helix axis oriented vertically. The presence of club shaped smooth lined cells, also suggested that Elipsoideichnus corresponds to the work of bees (Genise \& Hazeldine, 1998; Genise, 2000). However, this attribution was speculative because of the lack of more diagnostic characters or extant bees constructing helicoidal nests. The record of only one specimen in the Asencio Formation, which is famous for the diversity and abundance of bee nests, could also suggest that it was an aberrant specimen of something else.
The objectives of this paper are: 1) to present new material and localities for this trace fossil only known from its holotype until now, 2) to confirm its recurrent external and internal morphology as seen in several new specimens, reinforcing its validity as a distinct ichnotaxon, and 3) to present new unequivocal evidence supporting its bee origin.

\section{GEOLOGICAL SETTING}

The Asencio Formation crops out mainly in the western region of Uruguay, from Paysandú County in the northwest, to Colonia County in the southwest. It also appears in fragmentary patches in the central region of the country in Durazno and Flores counties, and in the southern region in Canelones County (Fig. 1). This unit overlies the Late Cretaceous Mercedes Formation and is overlain either by the Oligocene Fray Bentos or the Paleogene Quebracho formations (Alonso Zarza et al., 2011). Since there are neither index body fossils nor datable rocks in the Asencio Formation, its early Eocene age has been inferred based on stratigraphy, ichnologic content, and lateritic paleosols (Genise et al., 2002; Bellosi et al., 2004). It is characterized by its dark red colour, well sorted medium sandstones with ferric cements, and stacked Ultisols (González, 1999; Bellosi et al., 2004). Beyond controversial interpretations on age and origin, two main types of facies have been distinguished in the Asencio Formation since the first field observations (Rivas, 1884). One of tabular morphologies, submetric thickness, composed of massive sandstones and the other, commonly thicker, composed of centimetric nodules. Bellosi et al. (2004) interpreted these two facies as alternating stages of lateritic soils: duricrusts are formed during drier periods, whereas subsequent dismantling that occurs during more humid ones, result in the nodular levels.

Insect trace fossils are very abundant in the Asencio Formation, and can be found in both of the mentioned lithofacies. Nevertheless, the nodular facies seem to be more fossiliferous, perhaps due to an accumulation and condensation effect during dismantling. On the other hand, those nests in the nodular beds are not preserved in their original position. They have no prevailing orientation, on the contrary, they are randomly oriented reflecting slight movements and rotation due to dismantling processes (Gonzalez, 1999). Elipsoideichnus meyeri was never found in situ, but as detached clasts. In this scenario, the duricrusts would be the facies that should be surveyed in order to know its whole morphology, since specimens occurring in them would have not suffered any kind of movements or fragmentation. 

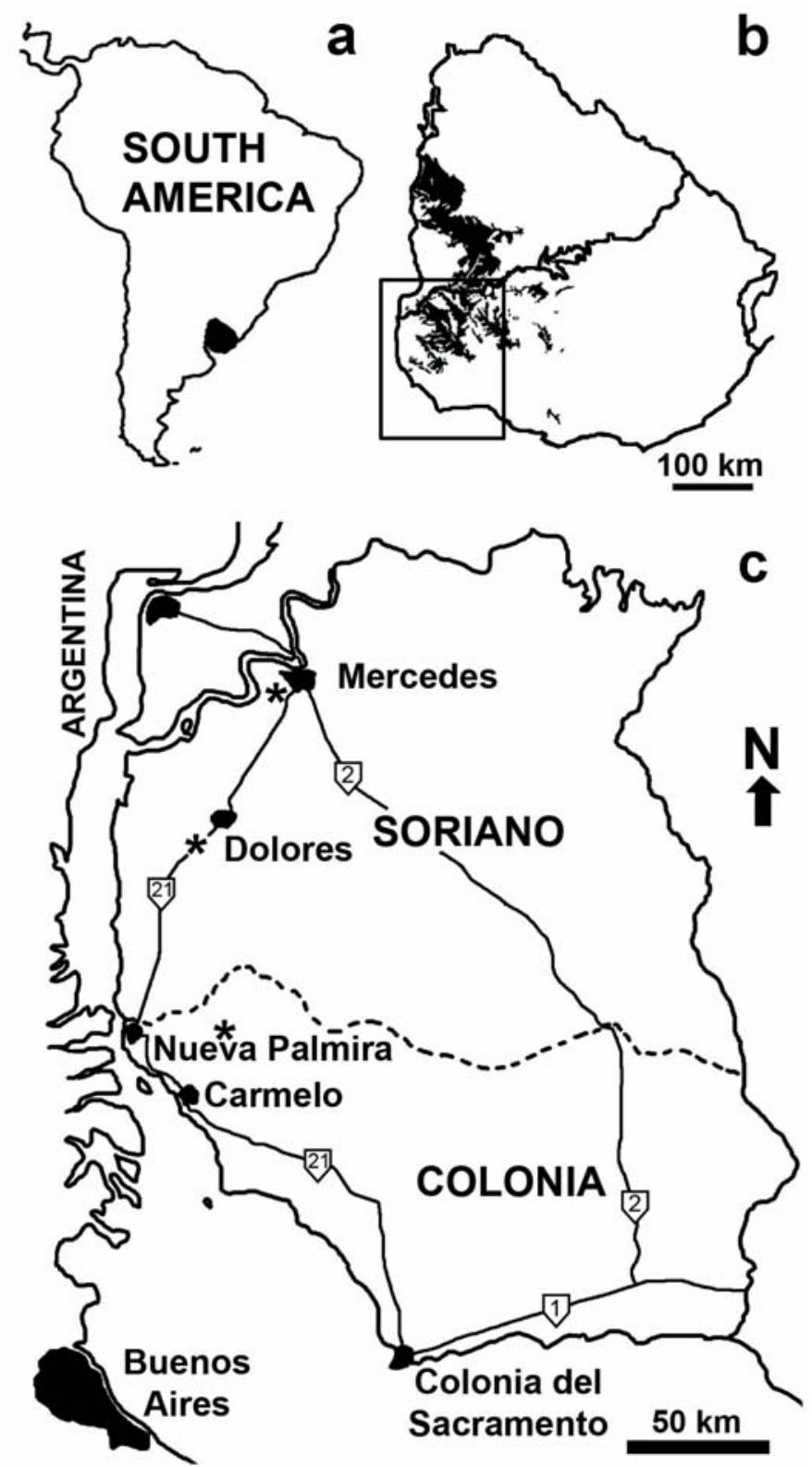

Figure 1. Geographic localities with Elipsoideichnus meyeri. a) Location of Uruguay. b) Geographic distribution of the Asencio Formation in Uruguay. c) Enlargement of the rectangular area in $b$, showing the localities of the Asencio Formation in the southwestern region of Uruguay (Soriano and Colonia counties), that yielded specimens of Elipsoideichnus meyeri (asterisks). From south to north: Las Flores Quarry (east of Nueva Palmira), Fontes Quarry (southwest of Dolores) and Dacá Quarry (southwest of Mercedes).

\section{MATERIALS AND METHODS}

The examined material is housed at the following institutions: Museo Municipal Francisco Lucas Roselli at Nueva Palmira, Colonia County (MLR); Colección Paleontológica de la Facultad de Ciencias at Montevideo,
Montevideo County (FCDP) and Museo Alejandro Berro at Mercedes, Soriano County (MAB). Since the holotype (MLR 705), was the only specimen recorded in the literature, special efforts were made to search new ones. Field work and the revision of collections at local museums of Colonia and Soriano counties yielded the new material. For 33 years, the availability of only the holotype specimen precluded any attempt to examine its internal structure by means of mechanical sections. The finding of new specimens enabled the possibility of choosing some of them for mechanical sectioning to observe closed cells. Thus, two specimens (FCDP 5226 and 5229), were cut using a water-cooled circular rock saw.

\section{SYSTEMATIC ICHNOLOGY}

Ichnofamily Celliformidae Genise 2000 Ichnogenus Elipsoideichnus Roselli 1987

Diagnosis. Helicoidal tunnel, circular in cross section, with its main axis vertically oriented. Each whorl bears internally two cells, arising from opposite sides of the whorl and connected to it by means of short, elbowed, lateral tunnels. Openings of lateral tunnels are also helically arranged along the main tunnel. Cells are clubshaped, thick lined, and show spiral closures (modified from Genise, 2000).

Remarks. The bauplan of this ichnogenus could be compared with that of Cellicalichnus since both ichnogenera share the presence of cells connected to tunnels. Cellicalichnus has straight to slightly sinuous vertical tunnels, whereas Elipsoideichnus has a helicoidal one. Other described helical trace fossils, such as Gyrolithes and Lapispira, lack cells.

Type ichnospecies. Elipsoideichnus meyeri Roselli 1987

Elipsoideichnus meyeri Roselli 1987

(Figs 2-3)

Synonymies.

1976 "palacio en espiral"; Roselli, p. 167.

1987 Elipsoideichnus meyeri; Roselli, p. 36.

1987 Elicoideichnus meyeri; Roselli, p. 56. Incorrect spelling.

1998 Ellipsoideichnus meyeri; Genise \& Hazeldine, p. 167. Incorrect spelling.

1999 Ellipsoideichnus meyeri; Genise, p. 29. Incorrect spelling.

2000 Ellipsoideichnus; Genise, p. 275. Incorrect spelling. 


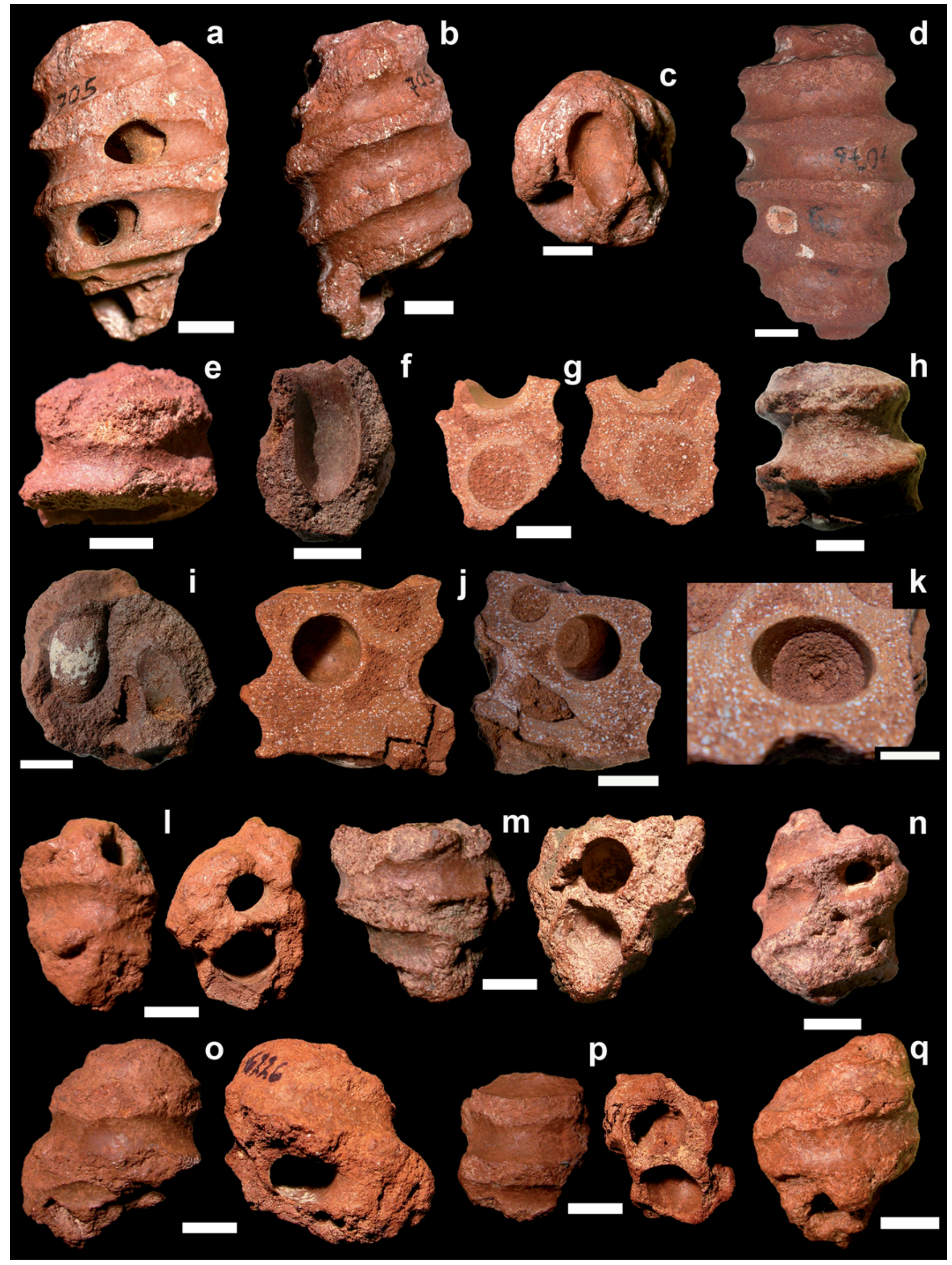


2004 Ellipsoideichnus; Genise, p. 423. Incorrect spelling.

2004 Ellipsoideichnus; Verde, p. 131. Incorrect spelling. 2008 Ellipsoideichnus; Verde \& Perea, p. 150. Incorrect spelling.

2010 Elipsoideichnus meyeri; Verde \& Genise, p. 66. 2012 Elipsoideichnus meyeri; Verde, p. 58.

Diagnosis. The same as for the ichnogenus.

Holotype. One specimen (MLR 705) showing six whorls, from the Asencio Formation, Las Flores Quarry (3351'53.12”'S - 58 11'29.15”W) (Figs 2a-c), located 19 km eastwards of Nueva Palmira, Colonia County, Uruguay. It is the southernmost locality where E. meyeri occurs. At present Las Flores Quarry is small and abandoned.

Examined material and distribution. Six specimens (MLR 1040) and (FCDP 5227-5229 and 6224-6225) from

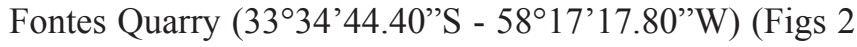
q, p, n, h-k, l, m, respectively), located $8 \mathrm{~km}$ southwest of Dolores, Soriano County, Uruguay. The Fontes Quarry, discovered during 2007 field work is a small quarry, but the most productive for this ichnogenus. Two specimens (FCDP 5226 and 6226) from Dacá Ranch Quarry (33 $18^{\prime} 10.46^{\prime \prime} \mathrm{S}$ - 58 4'41.95”W) (Figs 2e-g, o, respectively), located 6.5 $\mathrm{km}$ southwest of Mercedes, Soriano County, Uruguay. The Dacá Ranch Quarry, surveyed during 2008 field work, is relatively small and the northernmost locality where this ichnospecies occurs. One specimen (MAB 4082) originally found in the Museum Alejandro Berro, probably collected by its founder between 1927-1959, lacking geographic provenance (Fig. 2d). All specimens from the early Eocene Asencio Formation.

Description. The holotype (MLR 705) (Figs 2a-c) preserves only the inner half of the helical tunnel, $7 \mathrm{~mm}$ in diameter, and its internal core. The helix in the core, $60 \mathrm{~mm}$ high and $33 \mathrm{~mm}$ in diameter, shows 6 whorls inclined $16^{\circ}$. Each whorl bears two internal, opposite cells. Cell apertures in the helical tunnel are $7 \mathrm{~mm}$ in diameter and also helically distributed (Fig. 2a). Cells are $20 \mathrm{~mm}$ in length, $10 \mathrm{~mm}$ in diameter. At the upper end (Fig. 2c), only one cell can be seen. Specimen (MAB 4082) (Fig. 2d) is the only one as complete as the holotype. Its helix and internal core, $68 \mathrm{~mm}$ high and $37.5 \mathrm{~mm}$ in diameter, preserve almost 6 whorls, inclined $16^{\circ}$.

Although the other examined material is fragmentary and lacking complete whorls, these specimens show different aspects of the internal structure of this ichnotaxon, enabling additional description and measures (Figs 2e-q). The tunnel diameter can reach up to $9 \mathrm{~mm}$, whereas the smallest cells are $16.2 \mathrm{~mm}$ long and $8.2 \mathrm{~mm}$ in diameter, and the smallest tunnel apertures $5 \mathrm{~mm}$ in diameter. This fragmentary material corroborates computarized reconstructions by Genise \& Hazeldine (1998) about the piling up of cells in longitudinal sections (Figs 2g, 1-m, p) and the opposite arrangements of cells in cross sections (Figs 2i, 3b), which was also noticed by Roselli (1987). Specimen FCDP 5226 (Figs 2e-g), shows only one cell in cross section that corresponds to one end of the nest (compare with the holotype, Fig. 2c). The new material clearly shows the smooth lining of the club-shaped cells and a thick discrete wall (Fig. 2g). Specimen FCDP 5229 (Figs 2h-k) when sectioned, shows a spiral cap composed of five whorls (Fig. 2k).

\section{DISCUSSION}

The most common records of bee trace fossils involve isolated cells, such as ichnospecies of Celliforma and Palmiraichnus, or cells arranged in clusters, such as ichnospecies of Uruguay, Rosellichnus, and Corimbatichnus (Genise, 2000). Rarer are the cases of cells attached to tunnels, such as ichnospecies of Cellicalichnus, with a bauplan consisting of cells attached to a subvertical straight to sinuous tunnel, and Elipsoideichnus described herein. Such architecture likely reflects a common behaviour of bees, which is to line only cells with waterproof secretions to avoid diffusion of liquids from and to the soil. This lining would confer to cells a higher potential for preservation than for tunnels (Genise \& Bown, 1994). Elipsoideichnus, is a rare trace fossil, not only because of its limited record, but also because of the lined helical tunnel as reflected by its polished aspect (Figs 2a-b, d-e, $\mathrm{h}, \mathrm{l}-\mathrm{q})$. In addition, the morphology of E. meyeri is unique

Figure 2. Elipsoideichnus meyeri. a-c) Holotype (MLR 705); (a) lateral view showing the helical tunnel and tunnel entrances; (b) another lateral view with no entrances; (c) polar view with only one cell; d) specimen MAB 4082, tunnel apertures filled with sediment (white circular area on the lower left). e-g) FCDP 5226; (e) lateral view; (f) transverse cross section with only one cell (probably an end, compare to c); (g) two halves of the same specimen after sectioning, sand filled cells with a well defined wall can be seen piled up. h-k) Specimen FCDP 5229; (h) lateral view; (i) transverse cross section, showing two opposite cells; (j) two halves of this specimen after sectioning, with an empty cell; (k) empty cell showing a spiral cap. l-q) External and internal view of fragmentary material, showing the helical tunnel and piled up cells; (l) FCDP 6224; (m) FCDP 6225; (n) FCDP 5228; (o) FCDP 6226; (p) FCDP 5227; (q) MLR 1040. Scale bars $1 \mathrm{~cm}$, except in k (0.5 cm). 


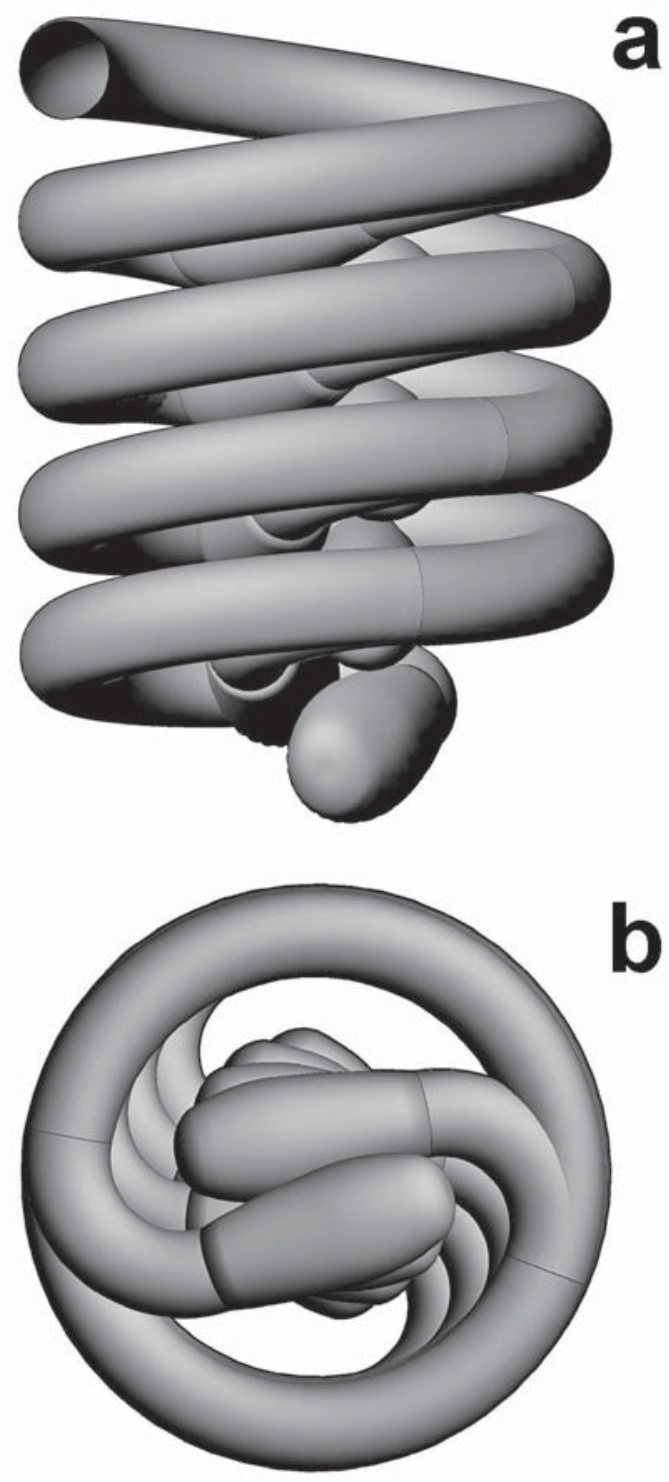

Figure 3. 3-D reconstruction of Elipsoideichnus meyeri. a) Lateral view of a specimen, where the helical tunnel can be seen. b) Cross section view with the opposedly oriented cells. Modified from Genise \& Hazeldine (1998).

and complex in the ichnological record. This morphology comprises a helicoidal tunnel, and internal cells arranged in pairs in each whorl, arising from opposite sides (Fig. 2i) and looking as a Ying-Yang symbol in cross section (Figs 3a-b). Tunnels openings along the main tunnel also display a helical arrangement.

The longest specimens comprise around 6 whorls (the holotype and MAB 4082), but there is no indication if they are complete specimens. Although the detailed morphology of Elipsoideichnus meyeri helix was reconstructed in 3D (Genise \& Hazeldine, 1998) (Figs 3a-b) and completed herein, the overall morphology of these trace fossils remains unknown due to the nature of the paleosols where they occur. All the findings correspond to loose specimens. Fracture and slight reworking of the insect nests during the dismantling processes of the Asencio Formation paleosols preclude the preservation of intact large structures such as long tunnels, that could be preserved under better taphonomic conditions. The rule is the preservation of chambers or group of chambers (calichnia and pupichnia), but no kind of peripheric structures, such as tunnels, have ever been found associated to them. This type of preservation precludes any inference about if the helical tunnel may continue with other parts of nests, or what is the morphology of the outer half of the tunnel.

The overall morphology of cells in Elipsoideichnus meyeri is similar to that of bees: a chamber with rounded rear and flat top (Genise \& Hazeldine, 1998; Genise, 2000). Also the smooth polished surface of the cells is similar to that of bees, probably a product of fluidization and bee secretions (Genise \& Poiré, 2000). Based on these characters, Genise \& Hazeldine (1998) attributed this trace fossil to bees.

However, it was until now that such attribution could be confirmed. During this research two specimens of $E$. meyeri were sectioned in order to search fingerprint key characters. One of them, FCDP 5226 (Fig. 2g), was filled with consolidated sandstone. The other one, specimen FCDP 5229, bears a closure cap with a spiral design in the inner face (Fig. 2k). The presence of this spiral cap could be considered an ethological autoapomorphy for Apidae (Genise, 1999). This unequivocal character confirms that bees are the constructors of E. meyeri (Verde \& Genise, 2010; Verde, 2012). Other bee characters identified in the new material include: 1) sediment filled elbowed tunnels, running between the spiral cap of the closed cell and the helix; and 2) thick cell linings (Fig. 2g) as in other bee trace fossils of the Asencio Formation, (e.g., Palmiraichnus and Uruguay).

In any case, there is no group of living bees that construct nests with helical tunnels like these. Moreover, there is no similar structure that can be postulated at least as a simplified version or "ancestor" of E. meyeri. Under this scenario, two groups of bees could be considered candidates as trace makers. One of them are sweat bees, particularly Halictini, which construct nests with cells directly attached to tunnels or by means of secondary short tunnels (Genise, 2000). If the main tunnels are coiled on themselves, the nest would result in a structure similar to Elipsoideichnus. Unfortunately, the lack of the external part of the helix in Elipsoideichnus precludes knowing if there were also external cells. Another group of bees, the Oxaeinae (Andrenidae) are also candidates. This is a small group of large bees inhabiting mostly subtropical and tropical South America, in lateritic soils and environments as those proposed for the Asencio Formation. These 
bees have been proposed as the producers of Uruguay and Palmiraichnus from the Asencio Formation (Genise \& Hazeldine, 1998). Such proposal is based on the similarity of Palmiraichnus with cells of extant Oxaeinae, and because Uruguay is a cluster of Palmiraichnus-like cells. The thick lining found in cells of Elipsoideichnus resembles that of Uruguay-Palmiraichnus-Oxaeinae cells and the filling of the elbowed tunnels, their antechambers.

\section{ACKNOWLEDGEMENTS}

Alvaro Achigar and his family discovered the Establecimiento Dacá Quarry and collaborated collecting some of the new specimens donated to the FCDP. Carol Torres, Fernanda Cabrera, and Felipe Montenegro helped during some field trips. Felipe Montenegro also collected one specimen and rediscovered the material at the MAB. Jorge Frogoni and Wilfredo Fernández from the Museo Francisco Lucas Roselli at Nueva Palmira facilitated the revision of the type material. The staff of the Alejandro Berro Museum and Pablo Toriño facilitated the loan of MAB 4082. Pablo Toriño also provided historical information about its founder. Natalia Seluchi kindly sectioned the specimens. Laura Sarzetti drawed Figure 3. Funds from the DINACYT and ANII (Grant FCE 2005010 and Grant FCE 2007-44 respectively) to M. Verde financed the fieldwork. CSIC also collaborated with a postgraduate grant to $M$. Verde. This research was part of M. Verde Ph.D. Thesis (PEDECIBA Program, Universidad de la República, Uruguay). This contribution is dedicated to the memory of our friend Jordi de Gibert, who shared with us the interest for helical trace fossils.

\section{REFERENCES}

Alonso-Zarza, A.M., Genise, J.F. \& Verde, M. 2011. Sedimentology, diagenesis and ichnology of Cretaceous and Palaeogene calcretes and palustrine carbonates from Uruguay. Sedimentary Geology, 236, 45-61.

Bellosi, E.S., González, M.G. \& Genise, J.F. 2004. Origen y desmantelamiento de lateritas paleógenas del oeste de Uruguay (Formación Asencio). Revista del Museo Argentino de Ciencias Naturales (n.s.), 6, 25-40.

Bown, T.M., Hasiotis, S.T., Genise, J.F., Maldonado, F. \& Brouwers, E.M. 1997. Trace fossils of Hymenoptera and other insects, and paleoenvironments of the Claron Formation (Paleocene and Eocene), Southwestern Utah. U.S. Geological Survey Bulletin, 2153-C, 42-58.

Genise, J.F. 1999. Fossil bee cells from the Asencio Formation (Late Cretaceous-Early Tertiary) of Uruguay,
South America. Proceedings of the First International Palaeoentomological Conference, Moscow, 1998, p. 27-32.

Genise, J.F. 2000. The ichnofamily Celliformidae for Celliforma and allied ichnogenera. Ichnos, 7, 267-282.

Genise, J.F. 2004. Ichnotaxonomy and ichnostratigraphy of chambered trace fossils in palaeosols attributed to coleopterans, ants and termites. In: The application of ichnology to palaeoenvironmental and stratigraphic analysis (ed. McIlroy, D). Geological Society of London Special Publications, 228, 419-453.

Genise, J.F. \& Bown, T.M. 1994. New Miocene scarabeid and hymenopterous nests and Early Miocene (Santacrucian) paleoenvironments, Patagonian Argentina. Ichnos, 3, 107-117.

Genise, J.F. \& Hazeldine, P.L. 1998. 3D-Reconstruction of insect trace fossils: Ellipsoideichnus meyeri Roselli. Ichnos, 5, 167-175.

Genise, J.F., Laza, J.H., Fernández, W. \& Frogoni, J. 2002. Cámaras pupales fósiles de coleópteros: el icnogénero Rebuffoichnus Roselli. Revista del Museo Argentino de Ciencias Naturales (n.s.), 4, 159-165.

Genise, J.F. \& D.G. Poiré, 2000. Fluidazation in insect constructions in soils. Ichnos, 7, 127-134.

Gibert, J.M. de, Mas, G. \& Ekdale, A.A. 2012. Architectural complexity of marine crustacean burrows: unusual helical trace fossils from the Miocene of Mallorca, Spain. Lethaia, 45, 575-585.

González, M.G. 1999. Los paleosuelos de la Formación Laguna Palacios (Cretácico superior) de Patagonia y la Formación Asencio (Cretácico superior - Terciario inferior) de Uruguay. Boletim do $5^{\circ}$ Simposio do Cretáceo do Brasil, p. 65-70.

Rivas, S. 1884. Nociones sobre el Departamento de Soriano. Anales del Ateneo del Uruguay, VI (34), 479-489.

Roselli, F.L. 1976. Contribución al estudio de la Geo Paleontología, Departamentos de Colonia y Soriano (República Oriental del Uruguay). IMCO, Imprenta Cooperativa, Montevideo.

Roselli, F.L. 1987. Paleoicnología, nidos de insectos fósiles de la cubierta Mesozoica del Uruguay. Publicaciones del Museo Municipal de Nueva Palmira, 1, 1-56.

Verde, M. 2004. Icnofósiles del Terciario de Uruguay. In: Cuencas Sedimentarias de Uruguay, Geología, Paleontología y Recursos Naturales. Cenozoico (eds Veroslavsky, G., Ubilla, M. \& Martínez, S.). DIRAC, Montevideo, 125-146.

Verde, M. 2012. Icnología de la Formación Asencio y las "Calizas del Queguay" (Cretácico tardio - Terciario temprano) del Uruguay. PhD. Thesis, Universidad de la República, Montevideo, Uruguay (unpublished).

Verde, M. \& Genise, J.F. 2010. Elipsoideichnus meyeri Roselli 1987, a fossil bee nest from the Eocene of Uruguay. I Latinamerican Symposium on Ichnology, Abstract Book, p. 66.

Verde, M. \& Perea, D. 2008. Icnofósiles. In: Fósiles del Uruguay (ed. Perea, D.). DIRAC, Montevideo, 135-159. 
